\title{
Sensitivity of Some Sweet Cherry (Prunus Avium L.) Genotypes To Late Spring Frosts During Different Phenological Stages Following Bud Burst
}

Ozkan Kaya ( $\sim$ kayaozkan25@hotmail.com )

Erzincan Horticultural Research Institute https://orcid.org/0000-0002-1679-6125

Cafer KOSE

Ataturk University

\section{Research Article}

Keywords: Freezing, Frost susceptibility, Floral bud developmental stages, Late spring frosts

Posted Date: November 16th, 2021

DOI: https://doi.org/10.21203/rs.3.rs-1034203/v1

License: (c) (i) This work is licensed under a Creative Commons Attribution 4.0 International License.

Read Full License 


\section{Abstract}

Sweet cherry (Prunus avium L.) is one of the economically important fruit crops worldwide. However, late spring frosts occurring in some years can significantly impact sweet cherry productivity through organ and tissue destruction caused by frost damage, and very little is known about frost tolerance or susceptibility of new cultivars. Differential thermal analysis (DTA) was, therefore, used to examine the exothermic characteristics (temperatures at which $50 \%$ of the flower buds were killed - mLTE values) of the flower buds belonging to members of the genus Prunus - 6 Prunus avium cultivars ('Noir de Guben', 'Bigarreau Gaucher', 'Merton Late', 'Merton Bigarreau', 'Van' and wild genotype). In the study, mLTE values of flowers of six cherry cultivars were determined at different floral bud developmental stages such as side green, green tip, open cluster, first white and full bloom under laboratory-based freeze assays for consecutive two years. The mLTE values of flower buds changed according to both different floral bud developmental stages and sweet cherry cultivars. In our findings, the mLTE values of flower buds in all cultivars generally occurred at higher temperatures in the open cluster stage, whereas the mLTE values of the flower buds in the first white stage occurred at lower temperatures, and therefore, these results are not only controversial in terms of previous frost tolerance studies, but also the first findings to be reported in literature. Considering the two-year average, the temperatures causing $\mathrm{mLTE}$ values for flower buds was -1.58 to $-3.74^{\circ} \mathrm{C}$ at the side green stage, -0.94 to $-3.51^{\circ} \mathrm{C}$ at the green tip stage, -0.41 to $-1.96^{\circ} \mathrm{C}$ at the open cluster stage, -2.30 to $-11.52^{\circ} \mathrm{C}$ at the first white stage and -2.37 to $-9.80^{\circ} \mathrm{C}$ at the full bloom stage in the range of six cultivars. In laboratory-based freezing experiments, the 'Van' cultivar were least affected by low temperatures, followed by 'Bigarreau Gaucher' cultivar and wild genotype. 'Merton Late' cultivar, on the contrary, was the most sensitive cultivar to low temperatures, followed by 'Noir de Guben' and 'Merton Bigarreau'. These results can be valuable in predicting possible frost damage at different developmental stages of the flower buds in sweet cherry.

\section{Introduction}

In many areas of the world, sweet cherry growing can be affected by autumn, winter and spring frost damage in different severity (Matzneller et al., 2016). This fact has been pointed out by many authors before (Proebsting and Mills1978; Miranda et al., 2005; Salazar-Gutierrez et al., 2014; Matzneller et al., 2016; Kaya et al., 2020). Spring frosts, which are among the lowest temperature restrictions especially of cherries growing, might cause more losses of fruit than any other biological and environmental hazards (Chmielewski et al., 2018). Although hardening provides adequate protection in dormant buds against frost damage in most cases, the situation becomes critical during the beginning of the growing season, when actively growing and dehardened buds are exposed to unpredictable spring frost events (SalazarGutierrez et al., 2014). It is known that many factors such as genotype, nutritive status of the pistil, water content of flower, ice formation in tissues, moisture content on the flower surface, flower starch and sugar content play a role on the tolerance or vulnerability of flowers against spring frosts (Westwood, 1993; Rodrigo, 2000). In particular, the water content of the flower plays a key role on its response to frost tolerance, and a low water content (53\%) in the bud of the sweet cherry cv 'Summit' has been detected 
during the dormant season (Götz et al., 2014). However, the water content of the buds that begin to swell increases concomitantly with the rising of air temperatures, which induces the beginning of the deacclimation phase during the spring (Chmielewski and Götz 2016). These changes are due to the progression of the phenological stages, that constantly decreases the frost tolerance of buds (Miranda et al., 2005; Proebsting and Mills 1978).

Histological evaluation and observations of the internal tissues of the flower buds, either during freezing or shortly after thawing have been carried out to determine damage caused by spring frosts in reproductive organs of sweet cherries (Proebsting and Mills1978; Götz et al., 2014; Salazar-Gutierrez et al., 2014; Matzneller et al., 2016; Kaya et al., 2020). Injuries caused by freezing in flowers often results in external and internal morphological abnormalities that cause flower or small fruit abscissions or even affect the normal development of the fruit (Matzneller et al., 2016). Therefore, when examined flower buds killed by spring frosts, they show a browning or a dark color as a general external symptom. Sometimes, frost damage of

ovary, style, and/or stamens is not noticeable from the outside of flowers, although the petals and sepals continue to develop in these flowers, the organ development arrests due to the damage of the pistil and the small fruits eventually drops. The first symptom observed when examining the flower organs at the full bloom stage is a dark discoloration of the pistil, that can extend to the ovules and style (Alhamid et al., 2018; Rodrigo 2000). However, the pistil and stamen organs inside flower that need to be examined, and the fact that they are embedded with whole flower and surrounded by petals and sepals structures, have made the interior of the flower difficult to monitor both under artificial frost conditions and during freezing in nature. An artificial freezing technique using differential thermal analysis was used to determine the critical temperatures of Prunus spp. flower buds, and this technique was suggested to be a reliable method for determining the critical temperatures of the flower buds during deacclimation (Kaya et al., 2020). DTA does not allow monitoring where ice formation begins in floral tissues, but a real-time exothermic analysis can be performed on the freezing response of reproductive organs using the technique under artificial frost conditions (Kaya et al., 2018; 2020; Kaya and Kose 2019).

Energy is released in the form of heat during the freezing of liquid water. This feature is utilized to monitor the freezing of flower bud and shoots in many deciduous fruit species using thermistors and thermocouples (Wisniewski et al. 1997 Freezing of the water inside the cells is lethal owing to the disappearance of a fluid internal environment necessary for the functioning of living protoplasm ceases (Kuroda et al., 1997). In general, two different temperature increases, called high temperature exotherm (HTE) and low temperature exotherm (LTE), occur in samples frozen under controlled conditions (Kaya and Köse 2017). HTE is represents the freezing of water in apoplastic/extracellular regions and it is not lethal. LTE following HTE peaks represents intracellular frost where the supercooling limit is exceeded, and they are lethal (Rende et al., 2018). Sometimes the HTE obtained from plant tissues is the only exothermic temperature that occurs, because water in the intracellular region does not supercool to a lower temperature than water in the extracellular region. In general, this event occurs widely in frost dehardened buds (deacclimation stage) during and after budbreak in spring (Kaya et al., 2020). In such 
cases, freezing occurs simultaneously in intracellular and extracellular regions in samples exposed to cold, and this single peak obtained from the sample is the lethal temperature (mLTE) value (Kaya et al., 2018; 2020; Kaya and Kose 2019; Malyshev et al., 2020). These single exotherms identified in several samples are used to accurately predict mLTE in the samples tested. To this end, DTA is the very easily applied and most robust when used in plant tissues such as leaves of olive, roots of grapevine, leaf disks of tomato, flower and flower organs of apricot which only have the HTE, as more water freezes in this case, resulting in an easily noticeable sudden temperature rise in the tissues (Fiorino and Mancuso, 2000; Gale and Moyer, 2017; Kaya and Kose, 2019; Kaya et al., 2018; 2020).

Information on frost tolerance of sweet cherry buds by using DTA during deacclimation are few in literature. In previous studies (Kaya et al., 2020), freezing damage in cherry flower buds after spring frosts or artificial freezing assays was determined by examination of the browning discoloration in the pistil. In the current study, therefore, we addressed the following questions: $(I)$ is there any difference in frost resistance among flower buds within sweet cherry cultivars? (II) is there any difference in frost susceptibility among the main phenological stages of flower development (side green, green tip, open cluster, first white, full bloom)? (III) is there a relationship between early, mid or late-maturing cultivar and frost resistance?

\section{Materials And Methods \\ 2.1. Plant material}

The research was conducted for two consecutive years (2019/20 - early spring season - April-May) in an experimental sweet cherry orchard, planted in March 2007 in Erzincan-Uzumlu (39 $.42^{\prime}$ Eastern longitude and $39^{\circ} .42^{\prime}$ Northern latitude, $1470 \mathrm{~m}$, a.s.l.). On an area of $1800 \mathrm{~m}^{2}, 50$ sweet cherry trees of the cultivars 'Noir de Guben' (late ripening), 'Bigarreau Gaucher' (late ripening), 'Merton Late' (very late ripening), 'Merton Bigarreau' (mid-season ripening), wild genotype (very early ripening- since that sweet cherry is the earliest ripening variety among its sweet cherry genetic resources, it was included in the varieties tested) and 'Van' (late ripening) stand in rows with 10 trees each, aligned in south-west direction, with planting space of $6 \times 6 \mathrm{~m}$. Trees grafted on mazzard (Prunus avium L.) rootstock were trained as a steep leader system. Pruning, drip irrigation system, plant protection and fertilization were carried out in the same way for all cultivars. Winter and spring pruning were carried out annually maintaining the training system. Light formative pruning was also performed in the spring when the leaves begin to develop. Trees were drip-irrigated and the irrigation was applied at four fruit development stages (fruit set, pit hardening, fruit development and fruit bud differentiation stages). A low-nitrogen fertilizer, such as 5-10-10 (N, P, K), was applied once a year in the spring, about a month before bloom. Six cherry trees for each cultivar and a wild genotype were selected, and flower bud samplings were carried out at the development stages according to BBCH scale: side green (Stage 51), green tip (Stage 53), open cluster (Stage 55), first white (Stage 57) and full bloom (Stage 59). Then, flower buds on spurs (twigs lenght-10-15cm) were used for DTA analysis, sampling from 5 to 22 April in both 2019 and 2020. Four spurs for each cultivar and wild 
genotype were collected from each tree for every stage, and immediately transferred to the laboratory, where controlled freezing tests for DTA analysis were conducted on flower buds.

\subsection{Differential thermal analysis}

In order to define freezing episodes called exotherms in flower buds of cultivars for this study, we initially identified mean law low temperature exotherm ( $\mathrm{mLTE}$ ) values of the flower buds, using the DTA technique (Fig. 1- represents the steps of DTA analysis). The determination of mLTE values of the cultivars was carried out using the DTA technique reported by Kaya et al. (2020). The loss of the capacity to supercooling and xylem vessels continuity occur simultaneously after and during bud break, and in this stage ice may propagate immediately via the vascular system. They stated, therefore, that extracellular and intracellular frost damage (a single exotherm peak or cell death point) on flower buds or flowers occur concomitantly. This methodology is followed by order; the flower buds brought to the laboratory the side green, green tip, open cluster, first white and full bloom stages were separated from the spurs using a razor blade for DTA tests. The thermal conductive paste was applied to the surface of flower bud samples to detect easier exotherm temperatures or ensure heat conduction (Fig. 1a). Samples were then placed on nine wells of the modules in a tray that consisted of ten wells (TEMs, Melcor, Trenton, NJ). The tenth well is the thermistor that measures the temperature of the other nine wells. A total of four different TEM trays was used during a DTA run, samples were placed in 36 wells in each DTA run. The six samples were placed in each well of per tray (Fig. 1b), and one TEM tray was used for each cultivar and 54 flower buds for each sweet cherry cultivar in total were placed in one TEM tray for each development stage. After the cover of trays were closed, they were placed in a temperature-controlled programmable cabinet, which is reduced by $4^{\circ} \mathrm{C}$, starting from room temperature (Tenney Model TU-JR- Thermal Product Solutions, Williamsport, PA) (Fig. 1C). The samples in the cabin were held at $4^{\circ} \mathrm{C}$ for 1 hour, and then the cabin temperature was decreased to -32 degrees in $9 \mathrm{~h}$ by cooling rate at $4^{\circ} \mathrm{C} \mathrm{h}^{-1}$. Freezing test the cabin was conducted run twice times for each sampling time. That is, two freezer chambers were operated (analyzes were performed simultaneously to increase the statistical significance of the tests). The freezing episodes called exotherms of samples were recorded using the data acquisition system (Delphin Expert Key 200L, Data Acquisition System), and voltage signals obtained from each TEM were transferred momentarily to Excel (Fig. 1d). Six freezing peaks called exotherms from each wells were detected for DTA runs. From the determined six exotherms (Fig. 1e), the lethal temperature (mLTE) or the cell death point values reported here were detected by taking the mean of peak values, expressed as the lethal temperature for $50 \%$ of the flower buds or flowers (Kaya et al., 2020).

\subsection{Statistical analysis}

Data and standard error of mean of peak values on investigated flower buds of the six cultivars were performed with JMP statistical software (version. 7.0, SAS Institute Inc., Cary, NC). Initially, using a quantile-quantile plot it was detected whether the data set with lethal temperature values are normally distributed. Calculation of mLTE values of flower buds was estimated using Box-and-Whiskers plot analysis. The $1 \%$ of the spread was calculated based on the number of LT values between the 100th and 1th percentiles of the whisker and box plot. Within an experiment, the $1 \%$ and $100 \%$ of spread were also 
assessed separately for each different phenological stages and for each individual year of mLTE values. Differences between mLTE values of different cultivars and different development stages were tested with a one-way analysis of variance (ANOVA), and a subsequent Tukey's HSD test, homoscedasticity provided, at the significant level of $p \leq 0.01$. The mLTE values of flower bud represent the mean of the lethal temperature that kills $50 \%$ of the flower population ( $\mathrm{mLTE}$ ).

\section{Results}

\subsection{The mLTE values of flower buds for cultivars according to developmental stages}

A different individual or wide peak was obtained from each flower bud by DTA technique. The frost tolerance of flower buds in sweet cherry cultivars was significantly influenced by the phenological development stages and by the year. Frost resistance among phenological development stages differed significantly and in the case of $\mathrm{mLTE}$ values ranged from $-0.41^{\circ} \mathrm{C}$ (for Merton Late at open cluster stage) to $-11.52^{\circ} \mathrm{C}$ (for Van at first white stage). When all phenological development stages were taken together, frost resistance, independently from the cultivars, was significantly decreased by the open cluster stage, and interestingly the maximum tolerance to frost was detected in the white stage compared to other stages. The flower buds of all cultivars at the first white and full bloom stages tolerated lower temperatures than other phenologica stages (Tab. 1). In both years, the temperature span over which frost damage developed (mLTE) in Noir de Guben cultivar was $-2.05,-1.83$ and $-1.51^{\circ} \mathrm{C}$ at the side green, green tip and open cluster stage, respectively, and there was no difference in $\mathrm{mLTE}$ values of flower buds among these stages. 
Table 1

Lethal temperature (mLTE) of various flower buds from six sweet cherry cultivars during $2019-20\left({ }^{\circ} \mathrm{C}, \mathrm{X} \pm\right.$ $\mathrm{SE}, \mathrm{n}=54$ ).

\begin{tabular}{|c|c|c|c|c|c|c|c|}
\hline Year & $\begin{array}{l}\text { Phenological } \\
\text { stages }\end{array}$ & $\begin{array}{l}\text { 'Noir de } \\
\text { Guben' }\end{array}$ & $\begin{array}{l}\text { 'Bigarreau } \\
\text { Gaucher' }\end{array}$ & $\begin{array}{l}\text { 'Merton } \\
\text { Late }\end{array}$ & $\begin{array}{l}\text { 'Merton } \\
\text { Bigarreau' }\end{array}$ & 'Van' & $\begin{array}{l}\text { Wild } \\
\text { genotype }\end{array}$ \\
\hline \multirow[t]{5}{*}{2019} & Side green & $\begin{array}{l}-2.05 \pm \\
0.49 c^{\star}\end{array}$ & $\begin{array}{l}-2.56 \pm \\
0.89 c\end{array}$ & $\begin{array}{l}-1.58 \pm \\
0.31 \mathrm{~b}\end{array}$ & $\begin{array}{l}-2.03 \pm \\
0.69 c\end{array}$ & $\begin{array}{l}-3.16 \pm \\
0.29 c\end{array}$ & $\begin{array}{l}-2.59 \pm \\
0.46 c\end{array}$ \\
\hline & Green tip & $\begin{array}{l}-1.83 \pm \\
0.62 c\end{array}$ & $\begin{array}{l}-2.38 \pm \\
0.27 c\end{array}$ & $\begin{array}{l}-1.00 \pm \\
0.33 b\end{array}$ & $\begin{array}{l}-1.64 \pm \\
0.90 \mathrm{~d}\end{array}$ & $\begin{array}{l}-2.79 \pm \\
0.76 c\end{array}$ & $\begin{array}{l}-2.37 \pm \\
0.41 c\end{array}$ \\
\hline & Open cluster & $\begin{array}{l}-1.51 \pm \\
0.43 c\end{array}$ & $\begin{array}{l}-1.22 \pm \\
0.26 \mathrm{~d}\end{array}$ & $\begin{array}{l}-0.41 \pm \\
0.48 c\end{array}$ & $\begin{array}{l}-1.23 \pm \\
0.35 \mathrm{e}^{ \pm}\end{array}$ & $\begin{array}{l}-1.59 \pm \\
0.22 \mathrm{~d}\end{array}$ & $\begin{array}{l}-1.56 \pm \\
0.25 d\end{array}$ \\
\hline & First white & $\begin{array}{l}-7.80 \pm \\
0.67 a\end{array}$ & $\begin{array}{l}-9.31 \pm \\
0.56 a\end{array}$ & $\begin{array}{l}-2.30 \pm \\
0.62 a\end{array}$ & $\begin{array}{l}-7.57 \pm \\
0.28 a^{-}\end{array}$ & $\begin{array}{l}-11.08 \pm \\
0.22 a\end{array}$ & $\begin{array}{l}-9.07 \pm \\
0.43 a\end{array}$ \\
\hline & Full bloom & $\begin{array}{l}-6.56 \pm \\
0.43 b\end{array}$ & $\begin{array}{l}-8.27 \pm \\
0.53 b\end{array}$ & $\begin{array}{l}-2.37 \pm \\
0.28 a^{ \pm}\end{array}$ & $\begin{array}{l}-6.87 \pm \\
0.33 b\end{array}$ & $\begin{array}{l}-9.15 \pm \\
0.54 b\end{array}$ & $\begin{array}{l}-8.49 \pm \\
0.51 b\end{array}$ \\
\hline \multirow[t]{5}{*}{2020} & Side green & $\begin{array}{l}-2.42 \pm \\
0.29 \mathrm{~b}\end{array}$ & $\begin{array}{l}-3.18 \pm \\
0.62 c\end{array}$ & $\begin{array}{l}-1.95 \pm \\
0.18 b\end{array}$ & $\begin{array}{l}-2.42 \pm \\
0.72 b\end{array}$ & $\begin{array}{l}-3.74 \pm \\
0.35 \mathrm{c}\end{array}$ & $\begin{array}{l}-3.17 \pm \\
0.43 \mathrm{~b}\end{array}$ \\
\hline & Green tip & $\begin{array}{l}-1.89 \pm \\
0.72 b\end{array}$ & $\begin{array}{l}-1.65 \pm \\
0.52 d\end{array}$ & $\begin{array}{l}-0.94 \pm \\
0.40 c\end{array}$ & $\begin{array}{l}-2.38 \pm \\
0.20 \mathrm{~b}\end{array}$ & $\begin{array}{l}-3.51 \pm \\
0.49 c\end{array}$ & $\begin{array}{l}-2.87 \pm \\
0.47 \mathrm{~b}\end{array}$ \\
\hline & Open cluster & $\begin{array}{l}-2.19 \pm \\
0.26 \mathrm{~b}\end{array}$ & $\begin{array}{l}-2.71 \pm \\
0.16 c\end{array}$ & $\begin{array}{l}-1.96 \pm \\
0.42 b\end{array}$ & $\begin{array}{l}-1.50 \pm \\
0.18 c\end{array}$ & $\begin{array}{l}-1.92 \pm \\
0.35 d\end{array}$ & $\begin{array}{l}-1.75 \pm \\
0.31 \mathrm{c}\end{array}$ \\
\hline & First white & $\begin{array}{l}-7.56 \pm \\
0.21 \mathrm{a}\end{array}$ & $\begin{array}{l}-9.75 \pm \\
0.92 a\end{array}$ & $\begin{array}{l}-2.80 \pm \\
0.26 a\end{array}$ & $\begin{array}{l}-7.94 \pm \\
0.13 a\end{array}$ & $\begin{array}{l}-11.52 \pm \\
0.18 a\end{array}$ & $\begin{array}{l}-9.37 \pm \\
0.34 a\end{array}$ \\
\hline & Full bloom & $\begin{array}{l}-8.00 \pm \\
0.26 \mathrm{a}\end{array}$ & $\begin{array}{l}-9.08 \pm \\
0.41 b\end{array}$ & $\begin{array}{l}-2.81 \pm \\
0.13 a^{ \pm}\end{array}$ & $\begin{array}{l}-7.85 \pm \\
0.43 a^{2}\end{array}$ & $\begin{array}{l}-9.80 \pm \\
0.51 \mathrm{~b}\end{array}$ & $\begin{array}{l}-9.18 \pm \\
0.39 a\end{array}$ \\
\hline
\end{tabular}

The capacity of all sweet cherry cultivars to survive frost during the growing season strongly depended on the stage of phenological development. When the mLTE values of the cultivars averaged over the phenological stages were compared, a definite decrease in frost tolerance as blooming proceeded until the open cluster stage was characteristic to all sweet cherry cultivars irrespective to their frost tolerance levels. Considering the frost tolerance profiles of all cultivars, two major groups of phenological stages could be distinguished throughout the blooming, the first white and full bloom stage with lower mLTE values had significantly better frost tolerance than other stages with higher mLTE values. Comparing wild genotype and 'Van' cultivar together, the difference in frost tolerance of buds tended to be more pronounced during the side green stage than during the green tip stage; however, the differences were not significant in both years. The frost tolerance of Noir de Guben cultivar was classified into two groups basing on the mLTE values of flower buds estimated by the exothermic assessment of DTA tests, the 
order of frost tolerance was first white and full bloom stage > side green, green tip and open cluster stages in both years (Tab. 1).

\subsection{The MLTE values of flower buds for the development stages according to the cultivars}

Looking at the side green stage during two consecutive years, 'Van' cultivar exhibited the lowest mLTE values $\left(-3.16\right.$ and $\left.-3.74^{\circ} \mathrm{C}\right)$ and revealed the best response to low temperature under laboratory-based frost conditions, followed by 'Bigarreau Gaucher' cultivar $\left(-2.56\right.$ and $\left.-3.18^{\circ} \mathrm{C}\right)$ and wild genotype $(-2.59$ and $-3.17^{\circ} \mathrm{C}$ ). The most frost-sensitive cultivar was 'Merton Late' (flower buds damaged at -1.58 and $-1.95^{\circ} \mathrm{C}$ ), followed by 'Noir de Guben' and 'Merton Bigarreau' (flower buds damaged at -2.05 to $-3.18^{\circ} \mathrm{C}$ and -2.03 to $-2.48^{\circ} \mathrm{C}$, respectively) (Fig. 2). At green tip stage, similarly, the greatest frost tolerance was found in 'Van' cultivar, which after artificial sub-zero treatments, did show the lowest mLTE values compared to other cultivars, followed by 'Bigarreau Gaucher' culivar and wild genotype for 2019 and 'Bigarreau Gaucher' and 'Merton Bigarreau' cultivars for 2020. 'Merton Late' cultivar, however, showed the least tolerance to frost temperatures (highest mLTE values ) at the green tip stage in both years, followed by 'Noir de Guben' and 'Merton Bigarreau' cultivars for 2019 and 'Noir de Guben' and 'Bigarreau Gaucher' cultivars (Fig. 3). Considering the frost tolerance profiles of all cultivars, two major groups could be distinguished at open cluster stage for 2019, 'Merton Late' cultivar in the first group with higher mLTE values $\left(-0.41^{\circ} \mathrm{C}\right)$ had significantly higher sensitivity frost tolerance than other cultivars in the second group with lower $\mathrm{mLTE}$ values. At this stage for 2020 , the lowest value for $\mathrm{mLTE}$ values $\left(-2.71^{\circ} \mathrm{C}\right)$ was that of 'Bigarreau Gaucher' cultivar, which displayed a significant difference with respect to the other cultivars with the highest $\mathrm{mLTE}$ values, indicating a high degree of frost-tolerance (Fig. 4).

Between the two end points of blooming stage, i.e. after transitioning from open cluster stage to first white stage, a significant increase was determined in the frost tolerance of all cultivars. This increase was determined as 9.59 and $9.60^{\circ} \mathrm{C}$ in the frost tolerant ' $V a n$ ' cultivar, while these values were found as 1.89 and $0.84^{\circ} \mathrm{C}$ in the frost sensitive 'Merton Late' cultivar at the first white stage in both years. Additionally, the mLTE values of 'Bigarreau Gaucher', wild genotype, 'Noir de Guben' and 'Merton Bigarreau' cultivars increased from open cluster to first white stage by $8.09,7.51,6.29,6.34^{\circ} \mathrm{C}$ for 2019 and $7.04,7.62,5.37$ $6.49^{\circ} \mathrm{C}$ for 2020 , respectively (Fig. 5). During the full bloom stage in both years, 'Van' cultivar showed the highest frost tolerance, followed by 'Bigarreau Gaucher' cultivar and wild genotype, meanwhile, 'Merton Late' was the least hardy cultivar, followed by 'Noir de Guben' and 'Bigarreau Gaucher' cultivars (Fig. 6).

\subsection{The mLTE values of flower buds for cultivars according to ripening stages}

Freezing resistance significantly differed among cultivars based on ripening at all phenological development stages, and 'Merton Late' cultivar, which has very late ripening characteristics, was injured at higher temperatures than other cultivars, which have late, middle and very early ripening characteristics (Fig. 2, 3, 4, 5 and 6). Interestingly, there were significant differences in the mLTE among late ripening 
cultivars, and among these cultivars that mature late in all phenological development stages, 'Van' cultivar showed mLTE values lower temperatures, usually followed by 'Bigarreau Gaucher' and 'Noir de Guben', respectively. Considering all phenological stages of development, 'Merton Bigarreau' cultivar, which has mid-season ripening, was classified as sensitive to frost, whereas wild genotype, which has very early ripening, was classified as moderately frost tolerant (Fig. 2, 3, 4, 5 and 6).

\section{Discussion}

In this study, we evaluated the importance of exotherm characters on the response of the freezingresistance mechanism of flower buds. Our findings showed that a single-peaked exotherm per specimen was detected in the flower buds of cultivars exposed to DTA tests during the bud break stage, and they were considered as the lethal temperature for flower buds (Fig. 1e). Previous studies supporting our results have revealed that a single exothermic peak of flower buds of deciduous fruit crop species was detected using DTA during the bud break stage (Meng et al., 2007; Gil-Albert, 1998; Kaya et al., 2018; 2020; Kaya and Kose, 2019). Indeed, studies evaluating the freezing response of different organs such as herbal parts, flower buds, and flowers of some plant species have reported that single peak determined by DTA is reliable and acceptable in predicting the lethal temperatures of the buds (Fiorino and Mancuso, 2000; Gale and Moyer, 2017; Smith and Redpath, 2018; Kaya et al., 2018; 2020). In fact, these single exotherms in our findings could be explained by the hypothesis that the buds lose their deep supercooling capacity in species belonging to the sub-genus Prunus during the deacclimation stage (Ashworth, 1990; Rodrigo 2000; Kaya et al. 2018; 2020). Basically the number of exotherms depends on the presence or absence of xylem in the flower primordia or whether the vascular continuity of the xylem is associated with the shoot tissues. More clearly, since the continuity of the xylem vessels between the shoot and the flower is established during the bud break phase, the flower buds of many deciduous species lose their deep supercooling capacity, and so that the ice crystals in the bud tissues spread immediately via the vascular vessels (Wisniewski et al., 1997; Kuprian et al. 2016). In cases where xylem vascular connections are established between the shoot and the flower in the spring, freezing occurs simultaneously in the extracellular and intracellular regions of the bud tissues, and thus a single exotherm is obtained from the sample (Fiorino and Mancuso, 2000; Gale and Moyer, 2017; Kaya et al., 2018; 2020; Kaya and Kose, 2019).

In general, frost tolerance of sweet cherry flowers has been previously studied mainly under field and laboratory observation conditions (Miranda et al., 2005; Matzneller et al., 2016). These methods allow the measurement of frost damage of flowers at different phenological stages of bud burst and are performed visually by observing dark discoloration or browning of the pistil after samples exposed to freezing have been thawed at room temperature for 24 or $48 \mathrm{~h}$. However, it is not very clear to understand what temperature level causes the death of pistil organs in this method, and it is not practical to research a few samples. On the contrary, the exothermic temperatures (mLTE values) of the flowers of many deciduous fruit species were determined in different phenological stages with DTA, which is an easier and more difficult method (Kaya et al., 2020). In contrast to classic visual evaluation studies after and during bud burst, in this study we used the only DTA method, and flowers were exposed to frost in a temperature 
control transparent climate chamber, so that the mLTE values of flower buds in our study showed compliance with the results reported by Kaya et al. (2020).

Considering the phenological stages, it was seen that all cultivars were tolerant to frost at the side stage, and a partial decrease in frost tolerance occurred at the green tip stage (except for 'Merton Late' and 'Bigarreau Gaucher' cultivar for 2020), and the significant losses of frost tolerance occur at the open cluster stage (Tab. 1). Previous studies have reported a gradual decrease in the frost tolerance of the buds with the progression of phenological stages after bud burst. Investigations have shown that the tolerance of the buds to low temperatures usually follows the order of side green > green tip > open cluster > first white > full bloom according to phenological stages (Proebsting and Mills 1978; Miranda et al., 2005; Salazar-Gutierrez et al., 2014; Matzneller et al., 2016). In our study consistent with these results, it was found that frost tolerance gradually decreased in the buds from bud burst to the open cluster stage. But interestingly, in contrast to previous findings on frost tolerance of flowers at the first white and full bloom stages (Proebsting and Mills 1978; Andrews et al., 1983; Rodrigo 2000; Miranda et al. 2005; Salazar-Gutierrez et al., 2014; Matzneller et al. 2016; Alhamid et al., 2018), all cultivars in our study showed the highest frost tolerance at the first white and full bloom stage compared to other stages of development in both years. Our findings, however, seem to confirm the preliminary observations of Kaya et al. (2020) at the first white and full bloom stages. Although they did not test the frost tolerance of the buds in the open side green, green tip and open cluster stages, they determined the critical temperature values for the cherry flower buds in the first white $\left(-9.54^{\circ} \mathrm{C}=50 \%\right.$ damage $)$ and full bloom $\left(-9.19^{\circ} \mathrm{C}=50 \%\right.$ damage) stages. In this study, we focused on the hypothesis that flower buds have more cell count and water content at side green, green tip and open cluster stages, and so they may have shown mLTE values at higher temperatures. As is known, there may be one to four or five stalks (flowers) in a dormant cherry bud and these stems are reserved within sepal up to the open cluster stage. In other words, in the first white and full bloom stage, which are the stages after the open cluster stage, the flowers completely separate from the sepals. We, therefore, think that the water content and cell number of the flower buds tested in the first white and full bloom stages were low compared to other stages of development, and thus they exhibited mLTE values at lower temperatures. In studies supporting this hypothesis, it has been reported that high water content and tissue size in flower buds have a negative effect on freezing tolerance (Ashworth et al., 1983; Quamme, 1991). Although we assume that this may be related to the number of cells and water in the flower buds, we argue that the main reason for this may be due to different physiological, morphological and biochemical events and that more research should be carried out. Because, it has been reported that frost tolerance in plant occurs as a result of a complex process involving a series of physiological and biochemical events, such as changes in the accumulation of certain proteins, lipid-membrane compounds (Wisniewski et al., 2003; Chinnusamy et al., 2007).

In the study, mLTE values of sweet cherry flower buds differed depending on different developmental stages of flowering, year and cultivars. These variations can be explained by the differences among cherry cultivars, years and different phenological stages. It has, indeed, been reported that the response to low temperature of plants varies among the flower organs, rootstock and rootstock/cultivar combination, different developmental stages of flowering, among species and cultivars (Proebsting and Mills 1978; 
Guy, 1990; Köse, 2006). In general, 'Merton Late' 'Noir de Guben' and 'Merton Bigarreau' cultivars had the least hardy frost tolerance at side green, green tip, first white, and full bloom stages, while 'Van', wild genotype and 'Bigarreau Gaucher' were the highest cultivars in those development stages for both years (Fig. 2, 3, 5 and 6). At open cluster stage, on the other hand, there were significant differences in $\mathrm{mLTE}$ values of flower buds of the cultivars for both 2019 and 2020, but their mLTE values were obtained at temperatures below $-2^{\circ} \mathrm{C}$ (except for 'Noir de Guben' and 'Bigarreau Gaucher' for 2020). At this stage for 2019, 'Merton Late' was the most sensitive cultivar to low temperatures, while other cultivars were found to be more tolerant to low temperatures. Unlike 2019, in 2020, 'Bigarreau Gaucher' showed the most tolerance to low temperatures, while other cultivars reacted similarly to low temperatures (Fig. 4). The $\mathrm{mLTE}$ value differences in among cultivars tested under similar test conditions point out that there is a strong genetic component effectively leaving cultivars with dramatically different safety margins from freezing damage. It has been reported that frost tolerance of plant species, cultivar and organ are mainly related to genetic structure and also frost tolerance in plants is a complex biological process (Wisniewski et al., 2003; Szalay et al., 2019; Chinnusamy et al., 2007). Interestingly, mLTE values of all cultivars in open cluster stage occurred at higher temperatures compared to mLTE values obtained from flower buds of cultivars in other stages. These findings are both the first records in the literature in terms of frost tolerance responses of flower buds according to phenological stages in sweet cherry cultivars and offer a different perspective for subsequent frost tolerance studies. Although we assume that while discussing the above open set stage, the reason for this may be related to the cell number and size and water content, our hypothesis needs to be confirmed. With our current findings, it seems very difficult to explain why sweet cherry cultivars are more susceptible to frost in the open cluster stage compared to the other phenological stage. In this context, we assume that thanks to the physiological, morphological and biochemical studies to be carried out in the following years, the answers to our currently unexplained questions can be found.

On the other hand, mLTE values of flowers differed among cultivars based on ripening at all phenological development stages, and 'Merton Late' cultivar, which has very late ripening characteristics, was injured at higher temperatures than other cultivars, which have very early ripening, middle and late characteristics. Research supporting our results have been reported that frost tolerance is less in late maturing cultivars (Chaplin and Schneider, 1974; Köse, 2006). However, there were significant differences in the mLTE between late ripening cultivars at all phenological development stages, and between these cultivars that mature late, 'Van' cultivar showed mLTE values lower temperatures, usually followed by 'Noir de Guben' and 'Bigarreau Gaucher' cultivars, respectively. Additionally, wild genotype, which has very early ripening, was classified as moderately frost tolerant, whereas 'Merton Bigarreau' cultivar, which has mid-season ripening, was classified as sensitive to frost (Fig. 2, 3, 4, 5 and 6). Although the response of the studied cultivars to low temperatures contradicts with the above literature, we hypothesize that the response of cultivars to spring frost depending on the maturation time may be due to genetic characteristics. On the other hand, it is known that cell walls both thickened and rigid in the flower buds during the acclimation stage (Rajashekar and Lafta, 1996; Mathers, 2004). The opposite occurs during the deacclimation stage, and cell walls typically become thinner, decrease their tensile strength and increase their pore sizes. 
Perhaps, varieties showing mLTE values at higher temperatures typically have thinned cell walls, reduced tensile strength, and increased pore sizes. However, this assumption needs to be supported both by histological analysis and using different measurement techniques such as microscopic observation, cryomicroscopy and low temperature scanning electron microscopy.

\section{Conclusion}

The frost tolerance of sweet cherry flower buds can greatly fluctuate according to phenological change after bud burst, which underpins the importance of phenological stages that precede sampling when studying the frost resistance of flower tissues using DTA. The frost resistance of flower bud tissues in spring and the ability of buds to susceptible during this period suggests that minimum spring temperatures are critical for sweet cherry trees, even towards their frost range limits. Based on $\mathrm{mLTE}$ values in this study, the frost tolerance of sweet cherry cultivars were found to have significant differences. The results showed that 'Van' exhibited the highest frost tolerance, followed by 'Bigarreau Gaucher' and wild genotype. By contrast, 'Merton Late' exhibited the least frost tolerance, followed by 'Noir de Guben' and 'Merton Bigarreau'. Taking an evolutionary perspective, however, genetic characteristic of cultivars may have contributed to the greater frost tolerance developed by cultivars, such as 'Van' 'Bigarreau Gaucher' and wild genotype, having low tolerance requirements than cultivars, such as 'Merton Late', 'Noir de Guben' and 'Merton Bigarreau'. On the other hand, late spring frosts occurring at the open cluster stage seem to be decisive in determining sweet cherry cultivars fitness, because they occurred at the time at which their freezing tolerance is approaching their lowest level. Consequently, this study demonstrates the complexity of freezing events in flower buds of some cherry cultivars at different floral bud developmental stages. However, the results presented here show that the critical temperatures obtained for some cherry cultivars under controlled conditions may have an indicative value when making the decision of activating frost protection systems. Finally, in order to verify the mLTE values obtained from laboratory experiments using DTA and to make them more reliable, field observations must be made in subsequent studies.

\section{Declarations}

\section{Acknowledgments}

The authors would like to thank Yusuf Aksun for he support in providing sweet cherry cultivars samples for assessment.

\section{Compliance with ethical standards}

\section{Conflict of interest}

The authors declare no confict of interest.

\section{Consent to participate}


No persons were interviewed; all authors consent to participate in the research.

\section{Consent for publication}

All authors agree to the publication of the study.

\section{Funding Statement}

This research did not receive funding.

\section{Author Contributions}

OK conceptualized the topic addressed in the paper and wrote the manuscript. CK interpreted the results and data analysis.

\section{Availability of data and material}

The submitted work is original and is not published elsewhere in any form or language.

\section{Code availability}

Not applicable.

\section{Ethical approval}

This article does not contain any studies with human participants or animals performed by any of the authors.

\section{Informed consent}

Not applicable.

\section{References}

1. Alhamid, J. O., Mo, C., Zhang, X., Wang, P., Whiting, M. D., Zhang, Q. 2018. Cellulose nanocrystals reduce cold damage to reproductive buds in fruit crops. Biosystems engineering, 172, 124-133.

2. Andrews, P.K., Proebsting, E.L., Gross, D.C., 1983. Differential thermal analysis and freezing injury of deacclimating peach and sweet cherry reproductive organs. J.Am. Soc. Hortic. Sci. 108, 755-759.

3. Ashworth, E.N., 1990. The formation and distribution of ice within forsythia flower buds. Plant Physiol. 92, 718-725

4. Chaplin, C. E., \& Schneider, G. W. (1974). Peach rootstock/scion hardiness effects. Journal of the American Society for Horticultural Science. 99, 231-234.

5. Chinnusamy, V., Zhu, J., and Zhu, J. K. 2007. Cold stress regulation of gene expression in plants. Trends Plant Sci. 12, 444-451. 
6. Chmielewski, F. M., \& Götz, K. P. (2016). Performance of models for the beginning of sweet cherry blossom under current and changed climate conditions. Agricultural and Forest Meteorology, 218, 85-91.

7. Chmielewski, F. M., Götz, K. P., Weber, K. C., \& Moryson, S. (2018). Climate change and spring frost damages for sweet cherries in Germany. International journal of biometeorology, 62(2), 217-228.

8. Fiorino, P., Mancuso, S., 2000. Differential thermal analysis, supercooling and cell viability in organs of Olea europaea at subzero temperatures. Adv. Hortic. Sci. 23-27.

9. Gale, E.J., Moyer, M.M., 2017. Cold hardiness of Vitis vinifera roots. Am. J. Enol. Viticult. 68 (4), 468477.

10. Gil-Albert, F., 1998. Tratado de arboricultura frutal. Ecología del árbol frutal, vol. 2.Ediciones MundiPrensa, Madrid, 207p.

11. Götz, K. P., Chmielewski, F. M., Homann, T., Huschek, G., Matzneller, P., \& Rawel, H. M. (2014). Seasonal changes of physiological parameters in sweet cherry (Prunus avium L.) buds. Scientia Horticulturae, 172, 183-190.

12. Guy, C.L., 1990. Cold acclimation and freezing stress tolerance: role of protein metabolism. Annual review of plant biology, 41(1), 187-223.

13. Kaya, O., Kose, C. 2019. Cell death point in flower organs of some apricot (Prunus armeniaca L.) cultivars at subzero temperatures. Scientia Horticulturae, 249, 299-305.

14. Kaya, O., Kose, C., Donderalp, V., Gecim, T., Taskın, S. 2020. Last updates on cell death point, bud death time and exothermic characteristics of flower buds for deciduous fruit species by using differential thermal analysis. Scientia Horticulturae, 270, 109403.

15. Kaya, O., Kose, C., Gecim, T. 2018. An exothermic process involved in the late spring frost injury to flower buds of some apricot cultivars (Prunus armenica L.). Scientia Horticulturae, 241, 322-328.

16. Kaya, Ö., Köse, C. 2017. Determination of resistance to low temperatures of winter buds on lateral shoot present in Karaerik (Vitis vinifera L.) grape cultivar. Acta Physiologiae Plantarum, 39(9), 209.

17. Köse, C. 2006. Temperature exotherms of dormant buds of rootstock genotypes. Vitis: Journal of Grapevine Research, 45(3), 145-146.

18. Kuprian, E., Tuong, T. D., Pfaller, K., Wagner, J., Livingston III, D. P., Neuner, G. 2016 Persistent supercooling of reproductive shoots is enabled by structural ice barriers being active despite an intact xylem connection. PloS one, 11(9). e0163160.

19. Kuroda K, Ohtani J, Fujikawa S (1997) Supercooling of xylem ray parenchyma cells in tropical and subtropical hardwood species. Trees 12:97-106

20. Malyshev, A. V., Beil, I., \& Kreyling, J. (2020). Differential Thermal Analysis: A Fast Alternative to Frost Tolerance Measurements. In Plant Cold Acclimation (pp. 23-31). Humana, New York, NY.

21. Mathers, H. M. (2004). Supercooling and cold hardiness in sour cherry germplasm: Vegetative tissue. Journal of the American Society for Horticultural Science, 129(5), 682-689. 
22. Matzneller, P., Götz, K. P., Chmielewski, F. M. 2016. Spring frost vulnerability of sweet cherries under controlled conditions. International Journal of Biometeorology, 60(1), 123-130.

23. Meng, Q. R., Liang, Y. Q., Wang, W. F., Du, S. H., Li, Y. H., Yang, J. M., 2007. Study on supercooling point and freezing point in floral organs of apricot. Agricultural Sciences in China, 6(11), 1330-1335.

24. Miranda, C., Santesteban, L. G., Royo, J. B. 2005. Variability in the relationship between frost temperature and injury level for some cultivated Prunus species. HortScience, 40(2), 357-361.

25. Proebsting Jr., E.L., Mills, H.H., 1978. Low temperature resistance of develop-ing flower buds of six deciduous fruit species. J. Am. Soc. Hortic. Sci. 103,192-198.

26. Rajashekar, C.B. and A. Lafta. 1996. Cell wall changes and cell tension in response to cold acclimation and exogenous abscisic acid in leaves and cell cultures. Plant Physiol. 111:605-612.

27. Rende M, Kose C, Kaya O (2018). An assessment of the relation between cold-hardiness and biochemical contents of winter buds of grapevine cv.'Karaerik' in acclimation-hardeningdeacclimation phases. Mitteilungen Klosterneuburg, Rebe und Wein, Obstbau und Früchteverwertung, 68(2):67-81

28. Rodrigo, J. 2000. Spring frosts in deciduous fruit trees morphological damage and flower hardiness. Scientia Horticulturae, 85(3), 155-173.

29. Salazar-Gutierrez MR, Chaves B, Anothai J,Whiting M, Hoogenboom G., 2014 Variation in cold hardiness of sweet cherry flower buds through different phenological stages. Sci Hortic 172:161-167.

30. Smith, E., Redpath, L. 2018. Floral bud cold hardiness of southern highbush blueberry (Vaccinium corymbosum $\mathrm{L}$. interspecific hybrids) in response to late season fertilization.

31. Szalay, L., György, Z., Tóth, M. 2019. Frost hardiness of apple (Malus X domestica) flowers in different phenological phases. Scientia Horticulturae, 253, 309-315.

32. Westwood, M.N., 1993. Temperate Zone Pomology: Physiology and Culture, 3rd ed. Timber Press, OR, USA.

33. Wisniewski, M., Bassett, C., Gusta, L. V. 2003. An overview of cold hardiness in woody plants: seeing the forest through the trees. HortScience, 38(5), 952-959.

34. Wisniewski, M., Lindow, S. E., and Ashworth, E. N. 1997. Observations of ice nucleation and propagation in plants using infrared video thermography. Plant Physiol. 113, 327-334.

\section{Figures}




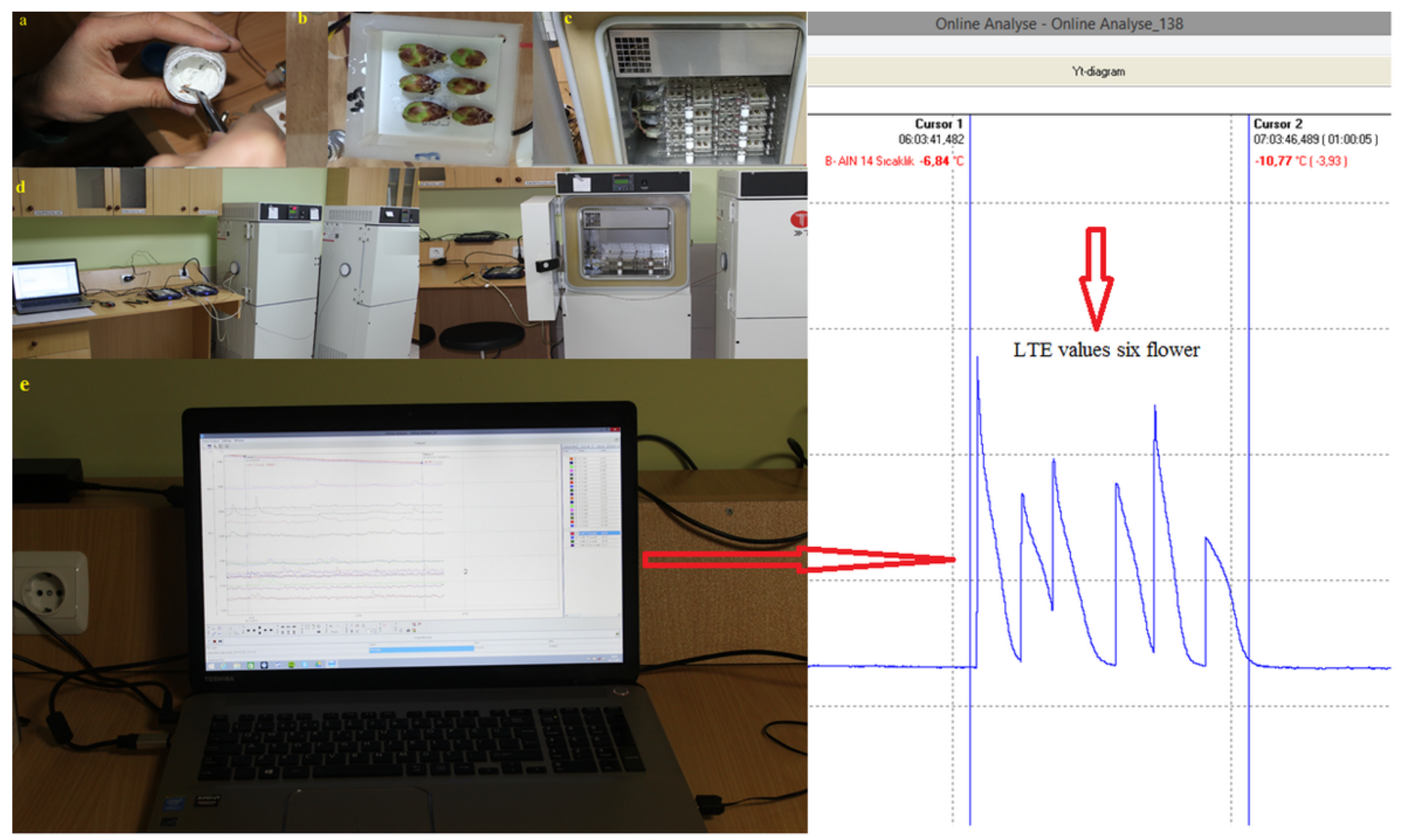

Figure 1

Each flower bud was placed in the thermoelectric modules $(a-b)$. The trays were placed into a programmable freezer chamber (c). Then data acquisition system recorded instant signals from each TEM and transferred voltage signal directly to Excel (d). Typical DTA profiles of lethal temperature ( $\mathrm{mLTE})$ from single TEM containing either flower buds (e). 


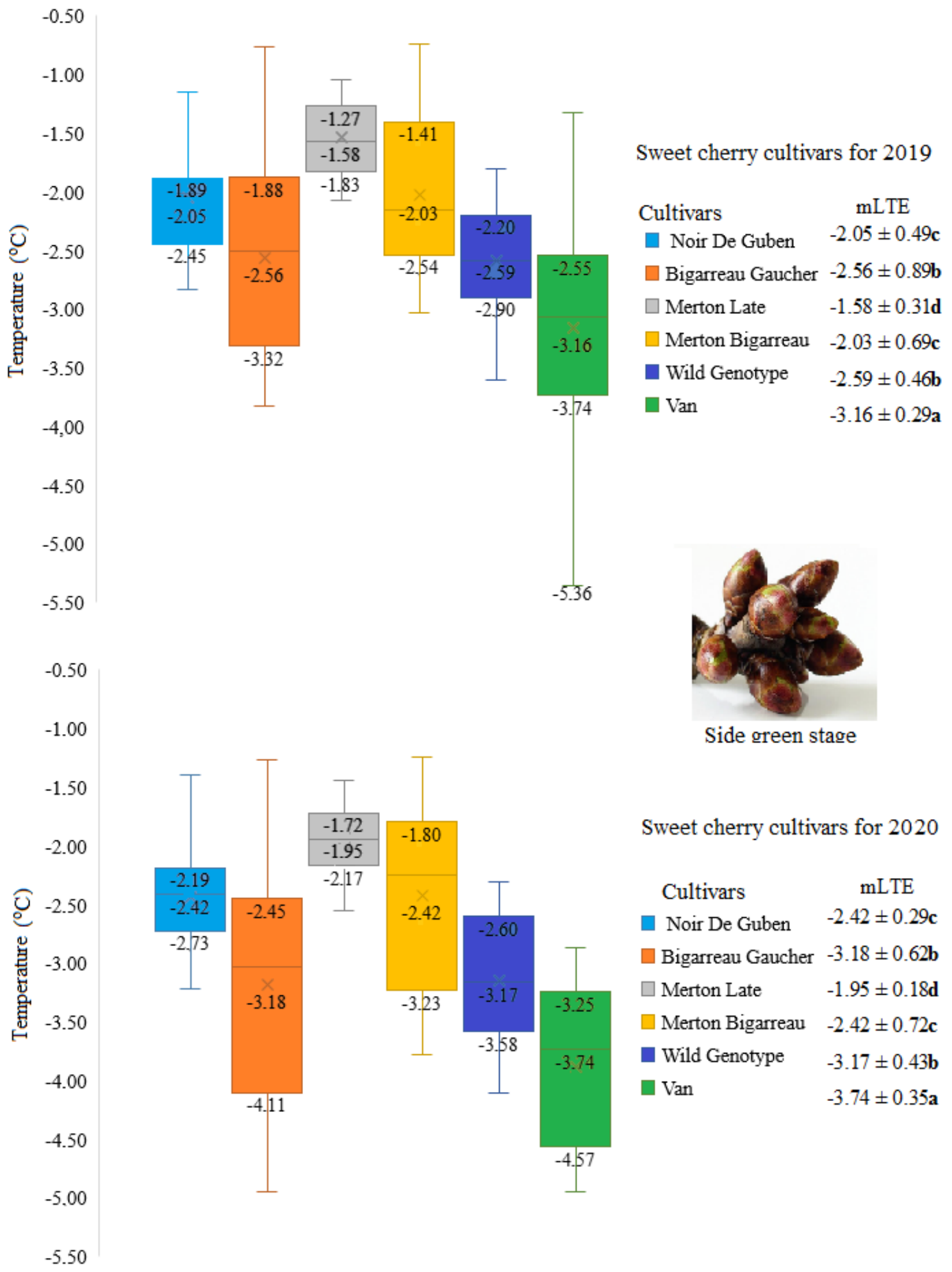

Figure 2

mLTE values detected for flower buds sampled on side green stage during 2019-20 (oC, $X \pm S E, n=54$ ). Different letters in the same column indicate statistically significant differences ( $m L T E, p \leq 0.01)$. 


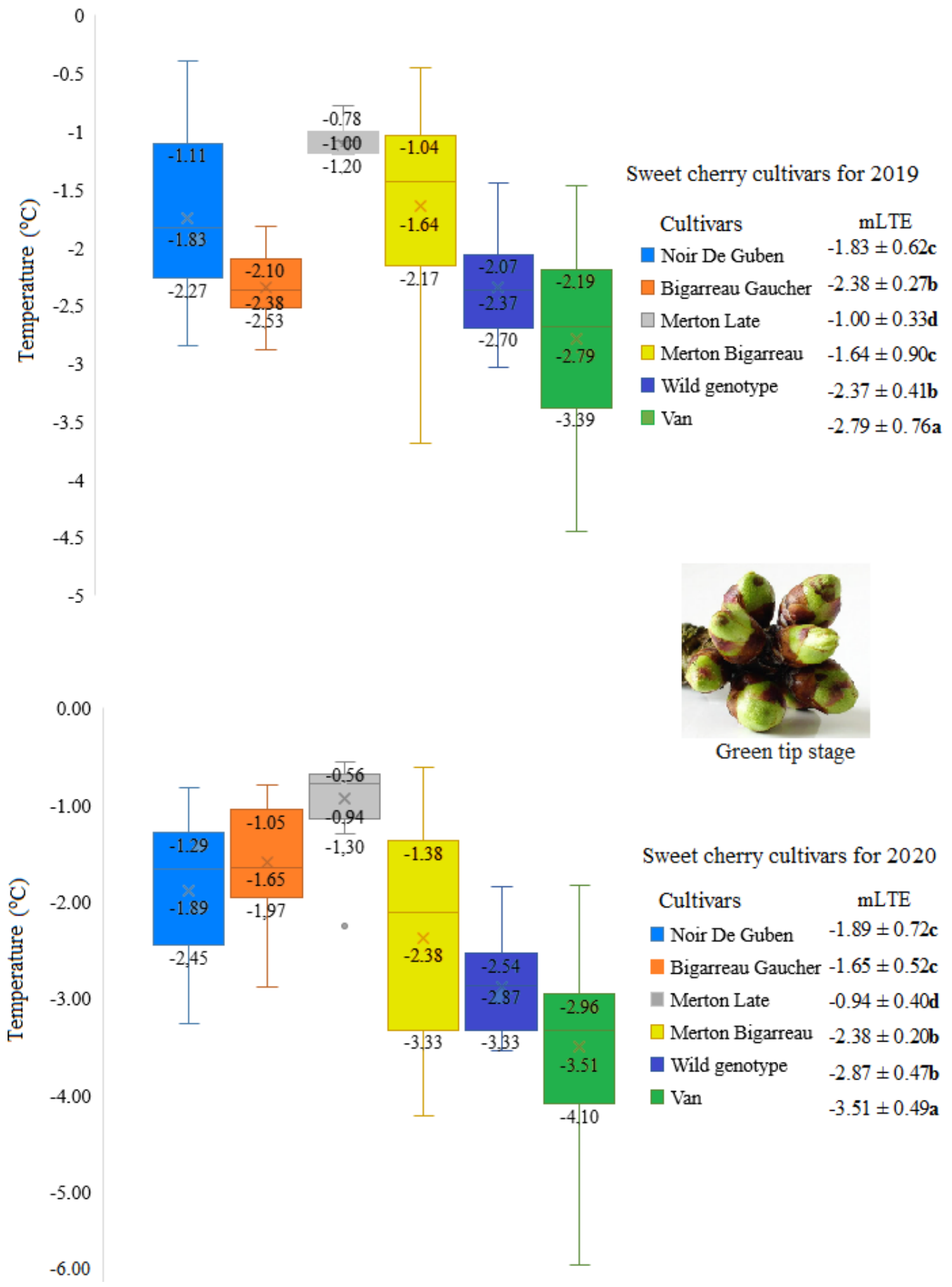

Figure 3

mLTE values detected for flower buds sampled on green tip stage during 2019-20 (oC, $X \pm S E, n=54$ ). Different letters in the same column indicate statistically significant differences ( $m L T E p \leq 0.01)$. 


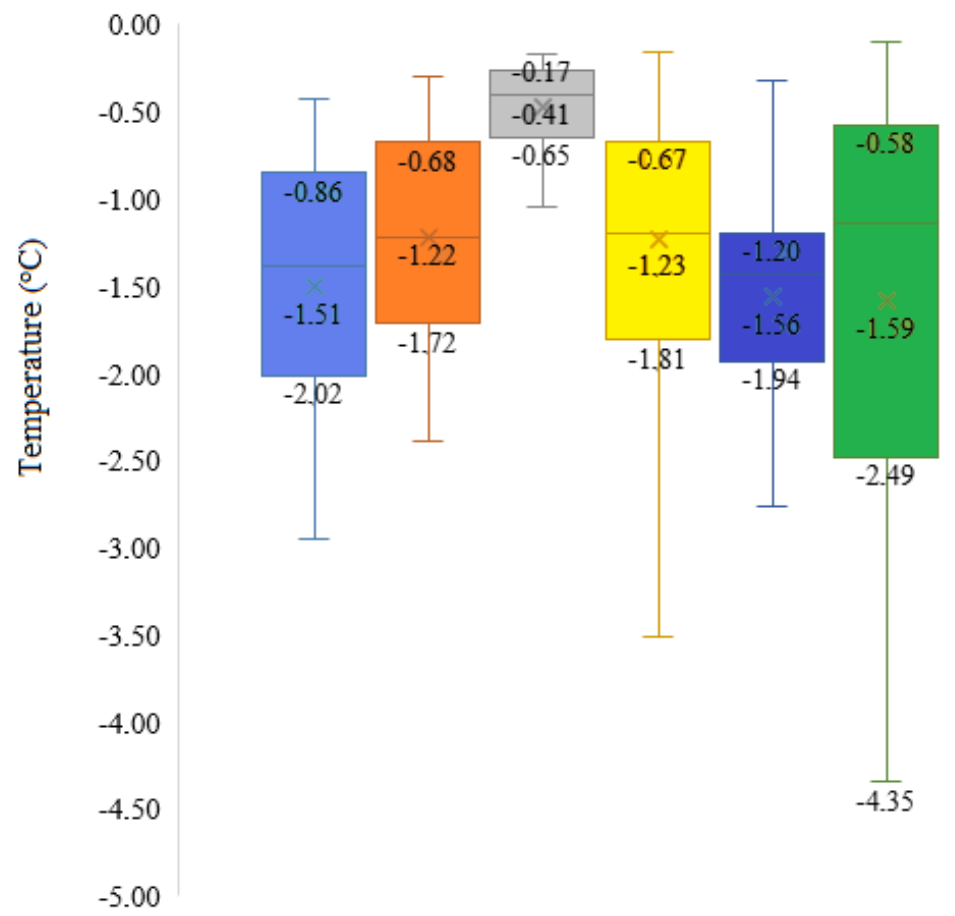

Sweet cherry cultivars for 2019

$\begin{array}{ll}\text { Cultivars } & \mathrm{mLTE} \\ \square \text { Noir De Guben } & -1.51 \pm 0.43 \mathbf{a} \\ \square \text { Bigarreau Gaucher } & -1.22 \pm 0.26 \mathbf{a} \\ \square \text { Merton Late } & -0.41 \pm 0.48 \mathbf{b} \\ \square \text { Merton Bigarreau } & -1.23 \pm 0.35 \mathbf{a} \\ \square \text { Wild genotype } & -1.56 \pm 0.25 \mathbf{a} \\ \square \text { Van } & -1.59 \pm 0.22 \mathbf{a}\end{array}$

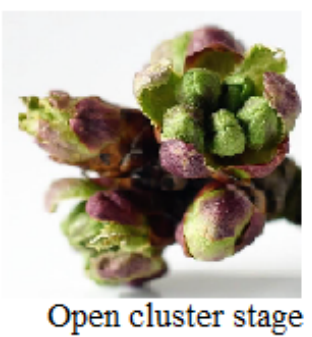

0.00

$-0.50$

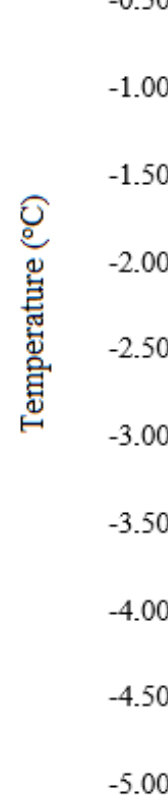
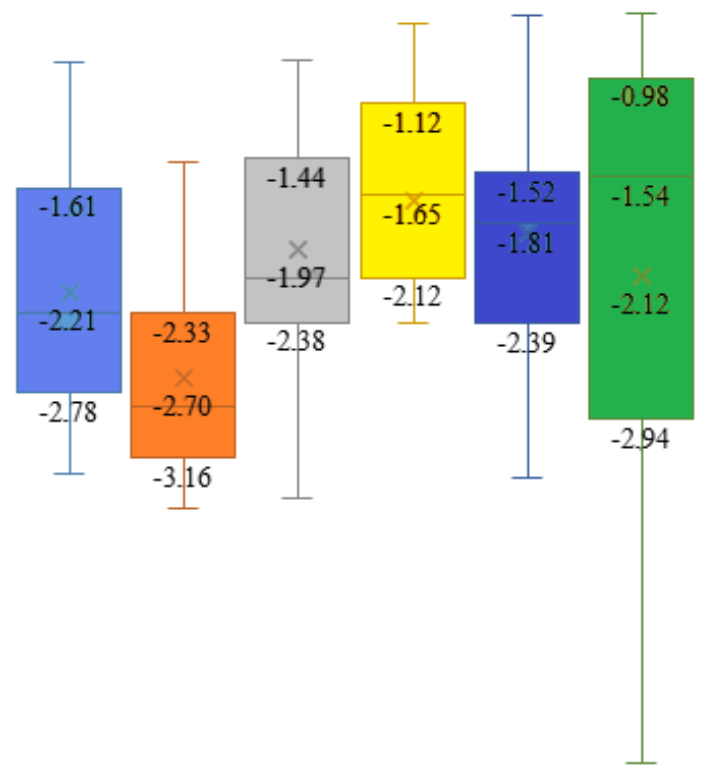

Sweet cherry cultivars for 2020

Cultivars

Noir De Guben

Bigarreau Gauche

$\square$ Merton Late

$\square$ Merton Bigarreau

Wild genotype

$\square$ Van
mLTE

$-2.19 \pm 0.26 b$

$-2.71 \pm 0.16 \mathrm{a}$

$-1.96 \pm 0.42 \mathbf{b c}$

$-1.50 \pm 0.18 \mathbf{c}$

$-1.75 \pm 0.31 b c$

$-1.92 \pm 0.35 b c$

\section{Figure 4}

mLTE values detected for flower buds sampled on open cluster stage during 2019-20 (oC, $X \pm S E, n=54$ ). Different letters in the same column indicate statistically significant differences ( $m L T E, p \leq 0.01)$. 

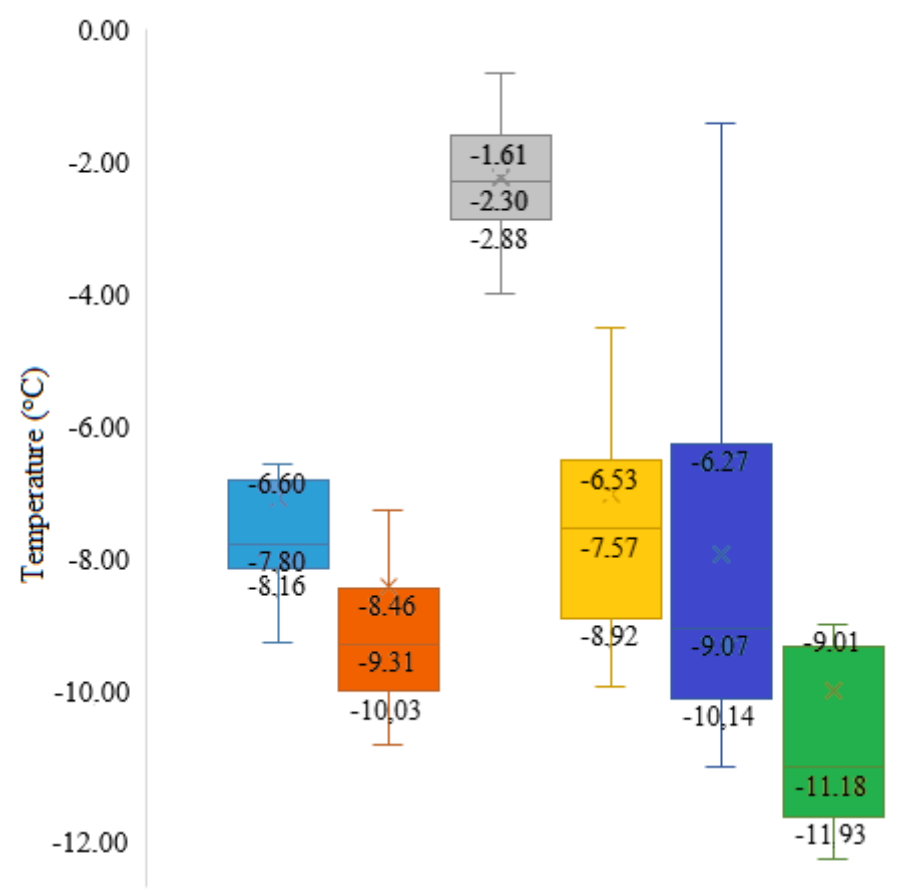

Sweet cherry cultivars for 2019

$\begin{array}{lc}\text { Cultivars } & \text { mLTE } \\ \square \text { Noir De Guben } & -7.80 \pm 0.67 \mathbf{c} \\ \square \text { Bigarreau Gaucher } & -9.31 \pm 0.56 \mathbf{b} \\ \square \text { Merton Late } & -2.30 \pm 0.62 \mathrm{~d} \\ \square \text { Merton Bigarreau } & -7.57 \pm 0.28 \mathbf{c} \\ \square \text { Wild genotype } & -9.07 \pm 0.43 \mathbf{b} \\ \square \text { Van } & -11.18 \pm 0.22 \mathbf{a} \\ & \end{array}$

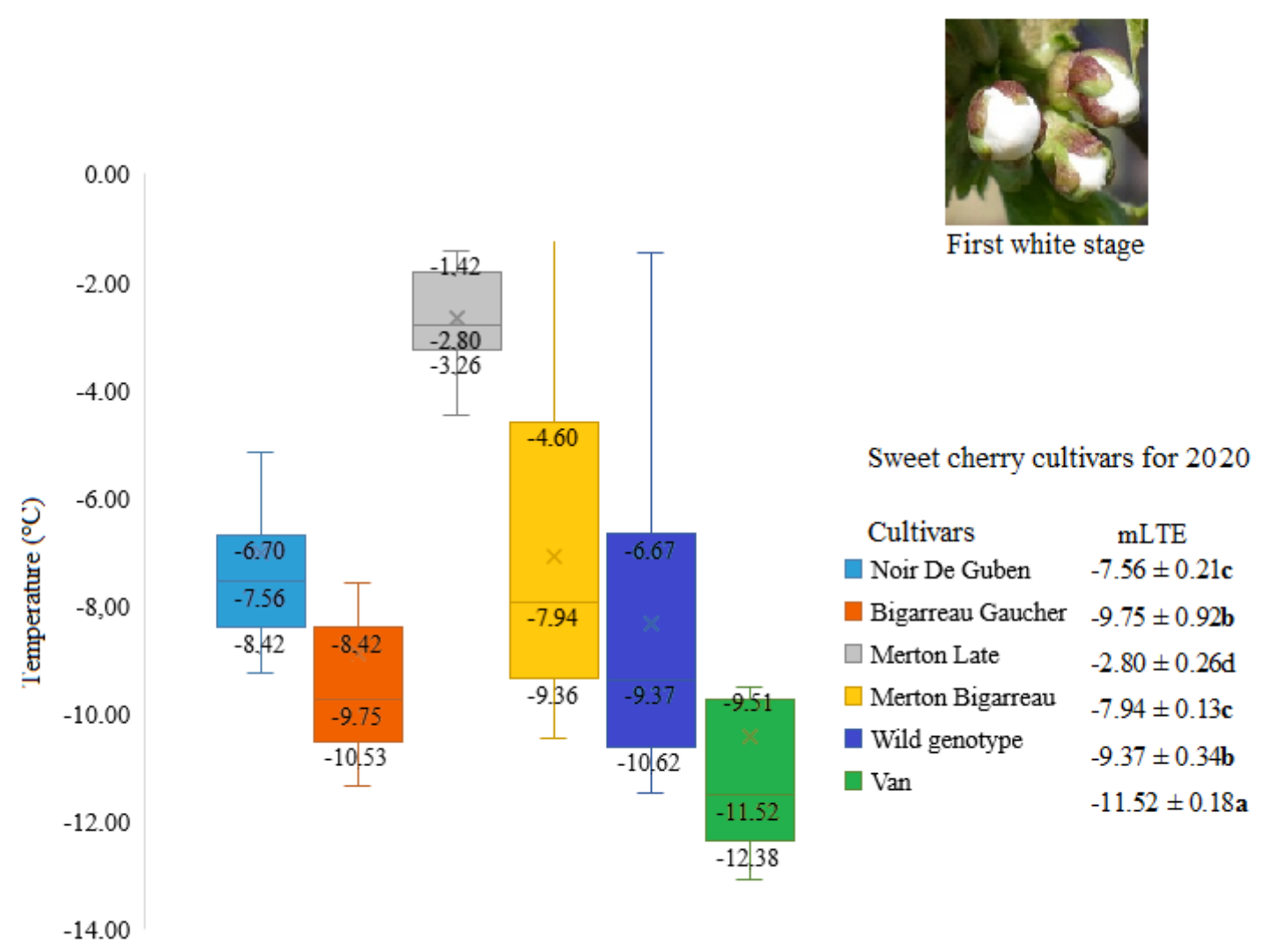

\section{Figure 5}

mLTE values detected for flower buds sampled on first white stage during 2019-2020 (oC, $X \pm S E, n=54$ ). Different letters in the same column indicate statistically significant differences ( $m L T E, p \leq 0.01)$. 


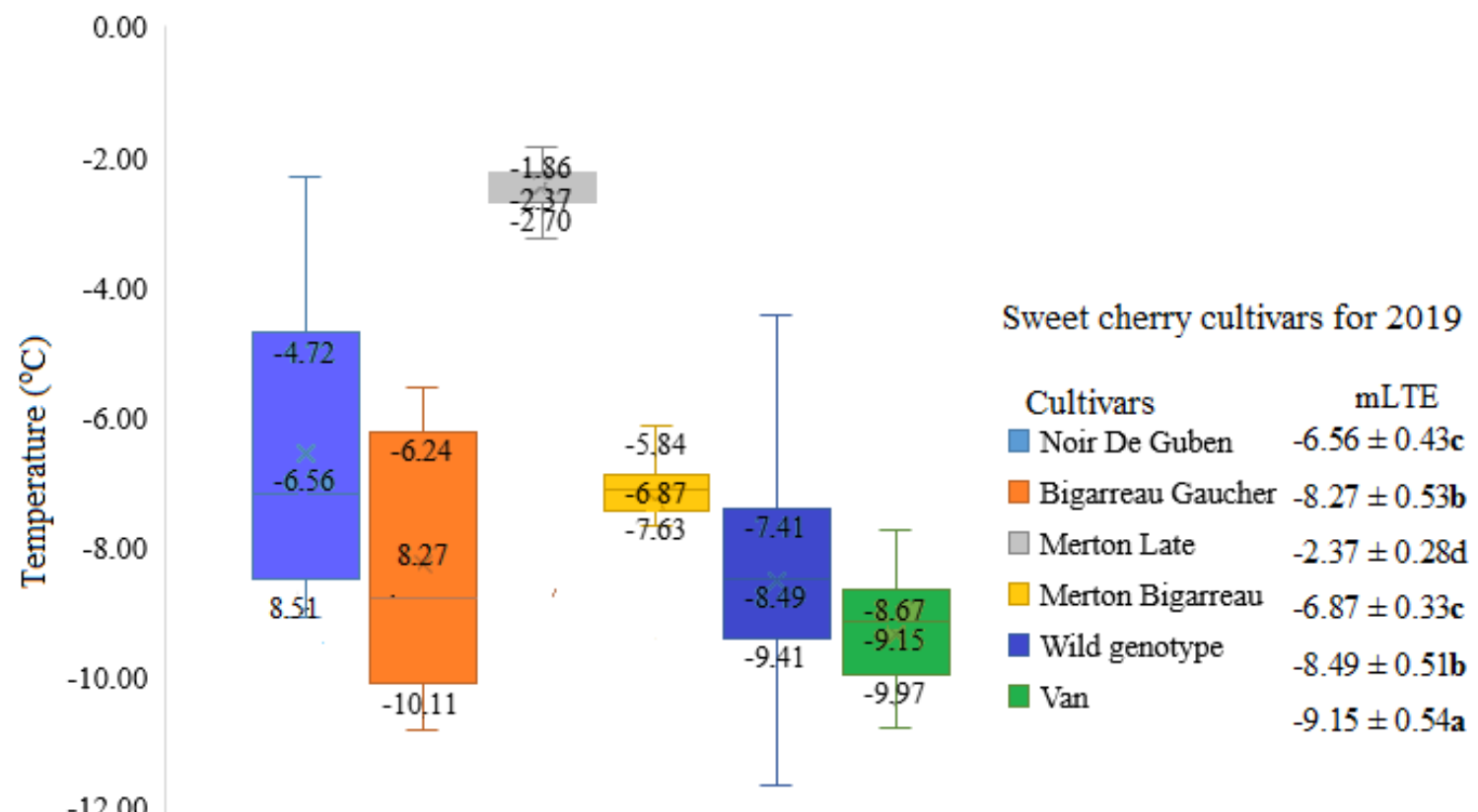

$-14.00$

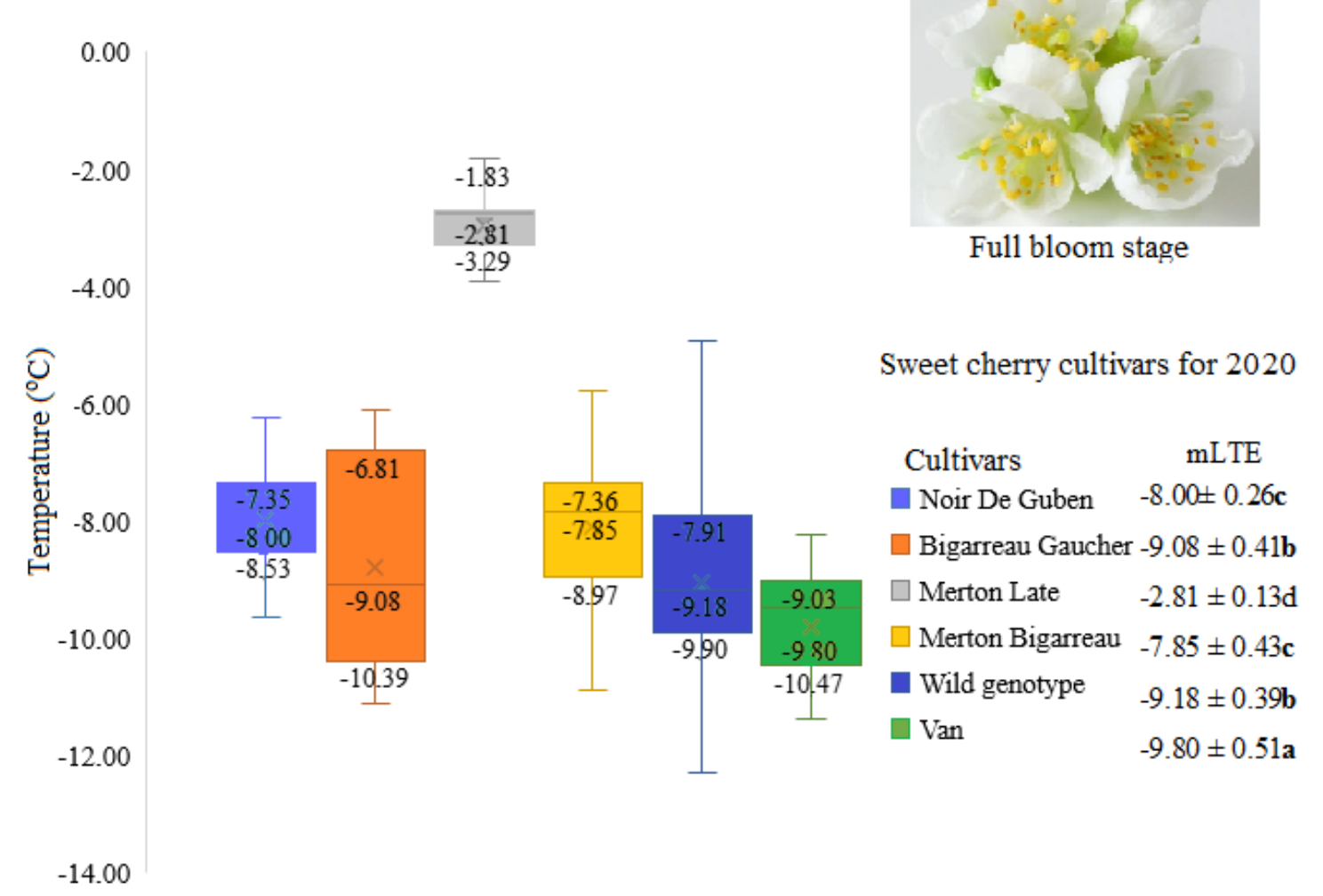

\section{Figure 6}

mLTE values detected for flower buds sampled on full bloom stage during 2019-20 (oC, $X \pm S E, n=54$ ). Different letters in the same column indicate statistically significant differences ( $m L T E, p \leq 0.01)$. 